\section{Royal Institute of Chemistry}

THE sixty-eighth annual general meeting of the Royal Institute of Chemistry was held on March 12. Referring in general terms to the annual report of the Council for 1945, the president, Prof. Alexander Findlay, said that membership of the Institute has increased by 459 to 9,641 and the register of students by 205 to 1,411 . Since the conclusion of hostilities, the activities of the Institute had expanded, and the Council had been concerned with reviewing almost every feature of the structure and work of the Institute to see where modifications and new developments were required in order to meet post-war needs. In his presidential address, which followed, Prof. Findlay referred to the tasks and responsibilities of the Institute in post-war Britain, and said that chemists must play an important part in the work of improving the physical and material well-being of the community. In all matters of national interest on which the activities of chemists impinged and in which the knowledge and experience of its members gave it a right to speak or act with authority, the Institute must, in the public interest, be more active in undertaking the duties and responsibilities of leadership in a spirit of service to the community. The Institute, probably in collaboration with other bodies, should exert itself in order to bring about, in the minds of the people as a whole, a better understanding of the nature and importance of the work of chemists and a consequent increase in the esteem in which the profession of chemistry is held by the community. During the War, chemists had made an important contribution to the achievement of victory, and they could make a no less valuable contribution to the rebuilding of our national life and to increasing industrial prosperity. But they must, without any thought of domination on their part or of claiming to force decisions in matters which lay outside their special province, be admitted to full and free collaboration with those who had the responsibility of framing policy and of administering the affairs of the countiy.

Dr. G. Roche Lynch, senior official analyst to the Home Office and director of the Department of Chemical Pathology at St. Mary's Hospital, London, was elected president for the year 1946-47. Dr. D. W. Kent-Jones has been appointed treasurer in succession to Mr. J. C. White, who served during the war years.

\section{West Wales Field Society}

Arr who know Pembrokeshire and the work of its Bird Protection Society will be interested to learn from its interim report, dated January 1946, that the Society has decided to change its name. Dr. Julian Huxley, moving the adoption of the seventh annual report, explained the wish of the Society to broaden the basis of its work and to include botany, zoology, geology and archæology in addition to the study of bird life and the interests of the countryside in general. He therefore proposed that the Society be called the West Wales Field Society, and this proposal was unanimously adopted. Dr. Huxley also referred to the bombing of the island of Grassholm, pointing out that Grassholm is the only island home of the gannets in the southern areas of England. He also said that the Society had done valuable service by securing the islands off the coast of Pembrokeshire as sanctuaries. The Council of the Society has decided to rent the islands of Skomer (with Middle. holm) and Skokholm for a while in order to try out the idea of establishing a field study centre there for the study of natural history and especially for the observation of the birds which use Skomer and Skokholm. The main centre will be at Skomer Island House, which can accommodate a small staff consisting of an honorary warden, a married couple to act as boatman and cook, and a succession of students. The Society has received the permission of Mr. Malcolm Stewart, one of its vice-presidents, to continue to supervise protection of the fauna of Grassholm and to do limited field work there. The Society's own yacht will be maintained for the use of its members. Something like $£ 1,000$ will be required for the maintenance of this field study centre during its first year, and the Society appeals for donations to support the work.

\section{Bulletin of War Medicine}

THe volume of scientific literature is nowadays so great, and the field that it covers is so wide, that no scientific worker can welcome the disappearance of a journal which abstracts any part of it. When the journal is one which has consistently maintained a high standard and has filled its pages with critical reviews written by experts it is even less pleasant to contemplate its disappearance. Yet we are no longer to have, after its issue of August 1946, the Bulletin of War Medicine. The Medical Research Council and the Bureau of Hygiene and Tropical Diseases, which issue it, have decided (Bull. War Med., 6, 61 ; 1945) that by that date the need for a journal of this kind will have been met. Now that the War has ended, it should become progressively less necessary to take into account the needs of medical officers serving overseas, so that it is proposed that the scope of the later issues of volume 6 shall differ somewhat in scope from that of the earlier issues. All the issues of the Bulletin will remain in print for the time being, so that the demand for complete sets of it can be met. The needs of medical men in the tropics will still be supplied by the Tropical Diseases Bulletin and the Bulletin of Hygiene, both of which are issued by the Bureau of Hygiene and Tropical Diseases.

\section{Capacity Current Heating}

THE demand for high-speed production in the war industries and the rapid advance made in radio technique during the War have been responsible for an expanding interest in the capacity current heating ('dielectric heating') of wood, rubber, plastic and other non-metallic materials. A report, Ref. Y/T6, entitled "Capacity Current Heating" prepared jointly by T. H. Messenger and D. V. Onslow, of the Research Association of British Rubber Manufacturers and the British Electrical and Allied Industries Research Association respectively, summarizes the position to date. The report is a résumé of published information. and it deals with the theory of this method of heating and, in some detail, with its applications. Equipment and costs are also considered. The report is supported by a bibliography of $\mathbf{2 4 1}$ references. Copies of the report may be obtained from the British Electrical and Allied Industries Research Association, 15 Savoy Street, W.C.2 (9s. net, postage $3 d$.).

\section{Exhibition in Sweden of British Scientific Instru- ments}

AN exhibition of British scientific instruments will be held in the Technical Museum, Stockholm, during May 24-June 4, under the joint auspices of the Scientific Instrument Manufacturers' Association of 